Limnol. Rev. (2014) 14,1: 13-20

DOI 10.2478/limre-2014-0002

\title{
Phases and interruptions in postglacial development of humic lake margin (Lake Suchar Wielki, NE Poland)
}

\author{
Danuta Drzymulska ${ }^{1}$, Piotr Zieliński \\ ${ }^{1}$ Department of Botany, Institute of Biology, University of Białystok, Świerkowa 20b, 15-950 Białystok, Poland, \\ e-mail: drzym@uwb.edu.pl (corresponding author) \\ ${ }^{2}$ Department of Hydrobiology, Institute of Biology, University of Białystok, Świerkowa 20b, 15-950 Białystok, Poland, \\ e-mail: p.zielinski@uwb.edu.pl
}

\begin{abstract}
Our study concerns the development of marginal zone of Lake Suchar Wielki (Wigry National Park). This humic lake is characterised by mire occurrence in its marginal zone, covered with a floating mat spreading on water surface. Biogenic sediments (peat archive) present in lakeside allow recognising the thousands years' development pattern of lake surrounded by mire. The wetland records were analysed for plant macroremains, degree of peat decomposition, sediment geochemical features along with age assessment. Morphological characteristics of the catchment were integrated with the wetland records. Our research showed that after the lake origin in the Allerød, accumulation in its marginal zone was interrupted, which was probably connected with high precipitation in the past. Slope processes could be possible. Stabilisation of environmental conditions took place in the younger Holocene. Despite these perturbations marginal zone of the lake was permanently terrestrial in character, as indicated by values of atomic C:N ratio.
\end{abstract}

Key words: humic lake, peat archive, hiatus, marginal zone of lake, C:N ratio

\section{Introduction}

Humic (dystrophic) lakes are characterised by presence of floating mats spreading on water surface comprised of mire vegetation, like roots and rhizomes of vascular plants (Scheuchzeria palustris, Cyperaceae, Ericaceae), peat mosses, and brown mosses. The type and pattern of sediment accumulation in lakes are determined by many external and internal environmental factors (Bloesch 2004). One of the most important factors is the water level, especially in the formation of littoral peat mires. And just specific feature of humic lakes is the occurrence of mire ecosystems in their nearest vicinity. As such, peat archive is an excellent record of past environmental conditions and past vegetation. It is possible to recognise histories spanning thousands of years in such lakes surrounded by mires. No such possibility exists for the vicinity of clear-water lakes, because of the lack of biogenic sediments (peat) in their marginal zone, which is connected with the lack of anoxic conditions (Drzymulska and Zieliński 2013). The peat archive includes macro- and micro- fossils which are complementary and altogether give a complete picture of peatland development (Rydin and Jeglum 2008). The subfossil remains of vegetation also inform about autogenic and allogenic changes on peatlands (Charman 2002).

In this research we comprise data derived from the sedimentary archive of Lake Suchar Wielki (Wigry National Park, northeastern Poland) (Fig. 1), which was previously used for palaeohydrological reconstructions (Drzymulska et al., 2014). The other palaeoecological studies of humic lakes located in the territory of Wigry National Park were conducted by Drzymulska et al. (2013) and by Drzymulska and Zieliński (2013). Contemporary vegetation and water quality of these lakes was studied by Pawlikowski et al. (2013).

Results of our investigations were complemented by the results of chemical analyses of sediments. Any influences of the aquatic environment on the development of the marginal zone of the lake are reflected in the nitrogen content in the lakeside sediments (Drzymulska and Zieliński 2013; Drzymulska et al. 2013). Organic matter of lacustrine origin is a 
major source of nitrogen, so the atomic C: $\mathrm{N}$ ratio is used to determine the domination of autogenic or allogenic sources of organic matter in sediments. The atomic C:N ratio for aquatic plants, phytoplankton, and zooplankton is 10 or below, whereas that for terrestrial plants exceeds 20 and can be as high as 45-50 (Meyers 1994; Ji et al. 2005).

Our objective was to: (i) recognise environmental conditions forming the water body from its origin in Allerød to the youngest Holocene (approximately 13000 years), (ii) reconstruct phases of lakeside development.

\section{Material and Methods}

Material for the study was collected from the littoral zone of the lake using a Russian sampler (50 $\mathrm{cm}$ long and $8 \mathrm{~cm}$ in diameter). The length of the core was $300 \mathrm{~cm}$. The core was divided into segments of $10 \mathrm{~cm}$.

The sample ages were determined indirectly by correlating the pollen spectra from the central parts of the analysed lakes with the radiometrically welldated profile from nearby Lake Wigry (Kupryjanowicz 2007). Pollen diagrams from one region and from the same period are similar in terms of basic features, permitting their correlation. When one diagram allowed assignment of absolute age dates, its timescale was then applied to a neighboring profile (RalskaJasiewiczowa et al. 2004). The complement of age assessment was ${ }^{14} \mathrm{C}$ AMS dating made in the Poznan Radiocarbon Laboratory (Poz) (the sample from the depth $263 \mathrm{~cm}$; dated material - stems of peat mosses). The radiocarbon age was calibrated with OxCal 4.2.3 (Bronk Ramsey 2013). The details concerning the age determination of the Lake Suchar Wielki sediments were presented by Drzymulska et al. (2014).

Peat samples collected for macrofossil remains analyses were flooded by distilled water with an addition of $10 \% \mathrm{KOH}$. The aim of that was full dispersion of peat lumps. Next suspension was boiled, then washed out through rinsed $0.2 \mathrm{~mm}$ sieve and peat was placed in Petri dish. At first, generative finds (fruits, seeds, fruit scales) from every sample were picked out

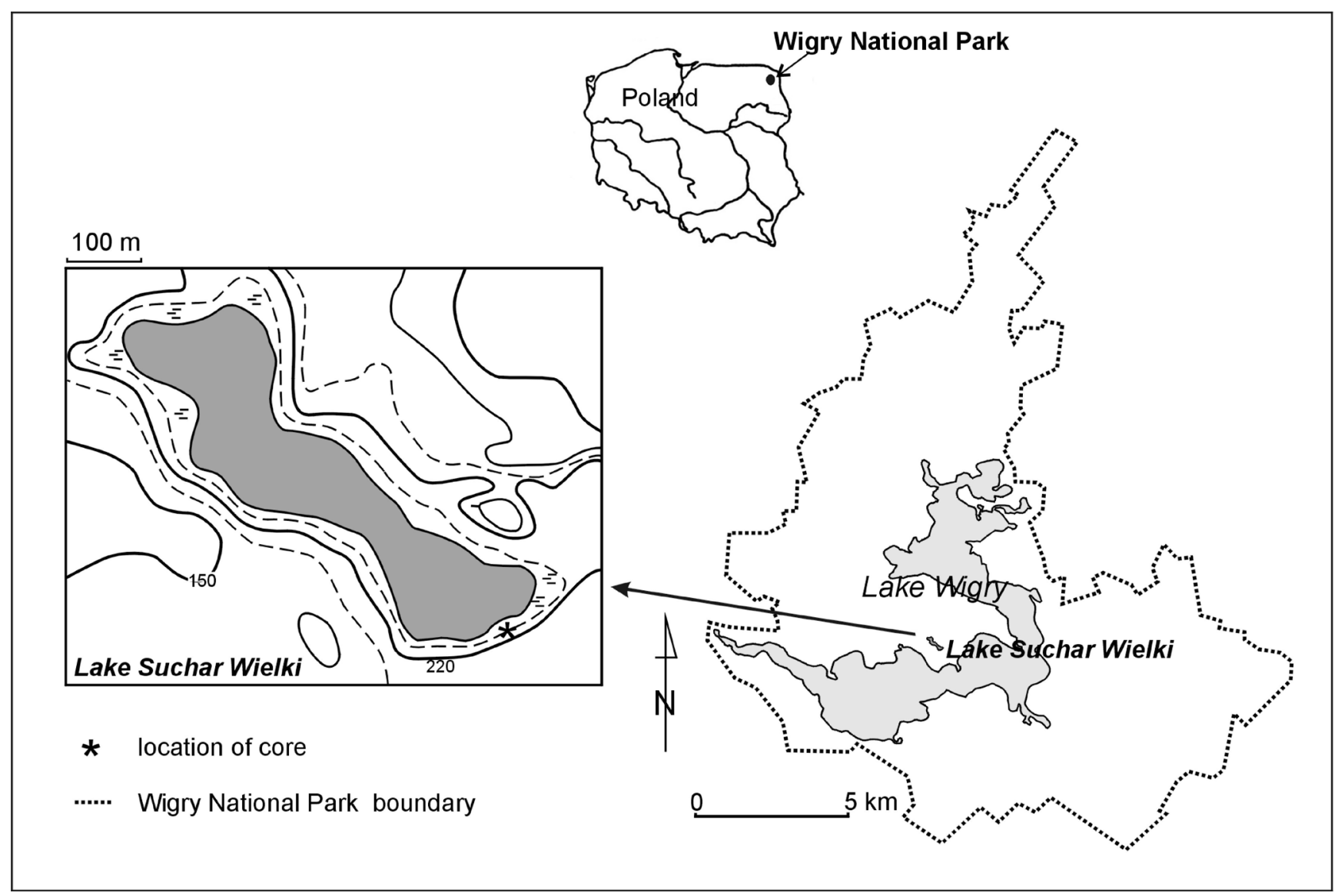

Fig. 1. The location of study lake in the Wigry National Park (NE Poland) 
and placed in other dishes. These finds were identified under a stereoscopic binocular microscope. Vegetative plant remains were identified with a light microscope. Different kinds of macrofossils were recognised: roots, periderm, epiderm, leaves, wood. For each sample, a proportion of every taxon tissues in total tissue mass was estimated. It was a base for fixing of peat units, which were classified according to Tołpa et al. (1967).

The next method was the microscopic analysis of the degree of peat decomposition. A ratio of completely humified peat mass to whole peat mass in ten fields of vision of microscope was fixed for every peat sample. According to Obidowicz (1990), peat may be divided into: slightly decomposed (decomposition up to $25 \%$ ), medium decomposed (30-40\%), highly decomposed (45-60\%) and humopeat (65\% and up). This parameter delivers information about humidity of the mire surface during the past peat forming process. A decrease in the degree of peat decomposition indicates a ground water table rise.

The obtained results were presented as diagrams drawn with the computer program POLPAL (Walanus and Nalepka 1999). Plant macrofossil zones were distinguished (Fig. 2).

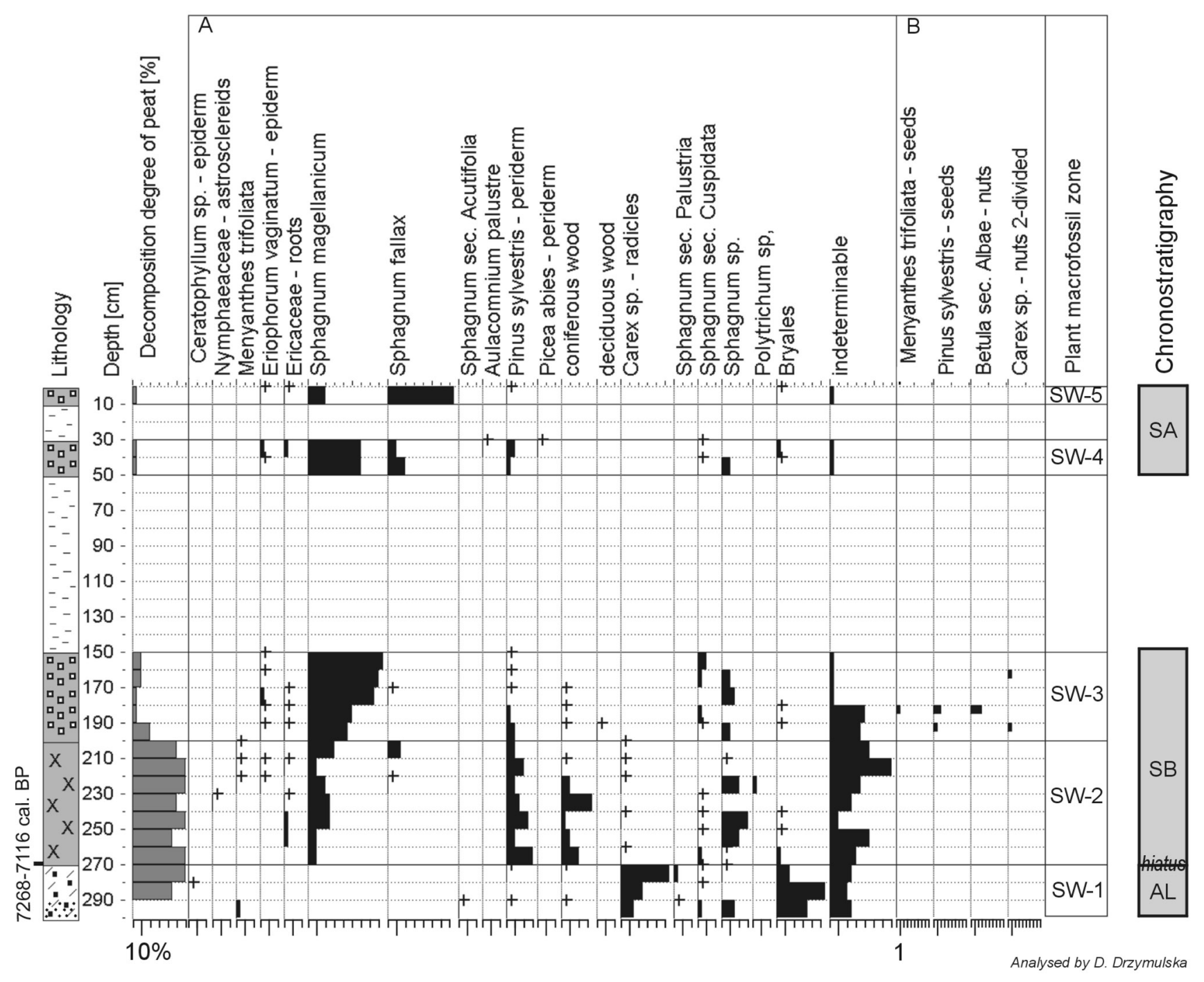

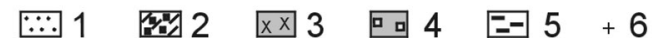

Fig. 2. Lake Suchar Wielki. Diagram of the macroscopic plant remains and decomposition degree of peat. A - vegetative remains, B generative remains, SA - Subatlantic period, SB - Subboreal period, Al - Allerød; 1 - sand, 2 - sedge-brown moss peat, 3 - Sphagnum peat with Pinus, 4 - Sphagnum peat, 5 - water, 6 - minimal amount 
Peat samples for chemical analyses were collected from the different depths of core. The intervals were 10-25 $\mathrm{cm}$ depending on the visible diversity of peat. The chemical characteristics of sediments were based on measurement of organic carbon (TOC) content, Kjeldahl nitrogen (TKN), and on estimation of atomic C:N ratio. Samples were tested for carbonates by treating with $10 \% \mathrm{HCl}$ and observing effervescence. Total carbon was determined by incineration of the samples in $550{ }^{\circ} \mathrm{C}$ for $5 \mathrm{~h}$ in a common furnace (Howard and Howard 1990). Kjeldahl nitrogen was determined on 0.25-1.0 g of dry sediment samples according to Bremner and Mulvaney (1982). Organic C, and Kjeldahl $\mathrm{N}$ values were corrected air-dried weight.

\section{Study area}

Lake Suchar Wielki is located in NE Poland, in the territory of Wigry National Park. Two physicalgeographical mesoregions - the East Suwałki Lakeland and the Augustów Upland, occur in this part of Poland. Both are included in the Lithuanian Lakeland (Kondracki 1994). The terrain of this area was shaped during the Pomeranian phase of the main stadial of the Weichselian (Vistulian) Glaciation (Marks 2002). The northern and middle parts of the park is characterised by a number of kames, eskers, and frontal moraine heights, while the southern part of the park comprises an extensive sandur. The climate of this area is temperate transitional between maritime and continental with a tendency toward continentality.

Lake Suchar Wielki is located west of Lake Wigry (Fig. 1). It is the biggest one among c.a. 20 humic lakes of Wigry National Park. Its area is approximately 30 times bigger than the area of the smallest Lake Suchar VI. The geographical position and parameters of the investigated lake are given in Table 1 .

The vegetation around Lake Suchar Wielki forms five concentric, physiognomically differing zones: (1) aquatic vegetation, (2) edge of floating mire, (3) floating (quaking) mire, (4) firm (non-quaking) mire and (5) pine woodland (P. Pawlikowski pers. commun.).

\section{Results}

Altogether three peat units were identified in studied profile: sedge-brown moss peat - strongly decomposed (300-270 cm), Sphagnum peat with Pinus - strongly decomposed $(270-200 \mathrm{~cm})$ and Sphagnum peat - slightly decomposed $(200-150 \mathrm{~cm}, 50-30 \mathrm{~cm}$, and $10-0 \mathrm{~cm}$ ). Decomposition degree of bottom sediment was not fixed because of strong sanding (Fig. 2).

Remains of 18 different plant taxa (species, section, genus) were identified in the investigated sediments. Among them, taxa characteristic of OxycoccoSphagnetea vegetation class were dominating. Quantitative representation of major plant types was as follows: trees and shrubs ( 3 taxa), dwarf shrubs (1), herbs (5), peat-mosses (6), brown mosses (3).

The peat-forming process began in the studied lakeside (SW-1 zone) during the Allerød, in the Late Glacial. After this interstadial accumulation of sediments was interrupted. The SW-2 and SW-3 zones are connected with the Subboreal period. The SW-4 and SW-5 zones - with the Subatlantic. The age of the lowest sample from the SW-2 zone is Atlantic (7268-7116 cal. BP; Poz-38254).

Five macrofossil zones were identified (Fig. 2). In the SW-1 zone (the Allerød interstadial) remains of brown mosses (max. 55\% in sample) and Carex sp. radicles (max. 50\%) dominate. Epiderm of Menyanthes trifoliata, periderm of Pinus sylvestris and Picea abies, and remains of peat mosses of Palustria, Acutifolia and Cuspidata sections are recored in lower percentage. The SW-2 zone (the Subboreal period) is characterised by approximately equal participation of the three main components of peat: Sphagnum magellanicum ( $\max 30 \%$ ), periderm of Pinus sylvesteris (max. 30\%) and periderm of Picea abies (max. 35\%). Remains of Eriophorum vaginatum, Menyanthes trifoliata, Carex sp., Ericaceae and brown mosses are represented in small amount. The SW-3 zone (the Subboreal period) comprise even $85 \%$ of Sphagnum magellanicum remains. Periderm of Pinus sylvestris, other peat mosses, epiderm of Eriophorum vaginatum, and roots of Ericaceaea are present. In the SW-4 zone (the Subatlantic

Table 1. Location and parameters of Lake Suchar Wielki (acc. Górniak and Krzysztofiak 2006)

\begin{tabular}{cccccccc}
\hline Latitude & Longitude & Area [ha] & $\begin{array}{c}\text { Maximum } \\
\text { depth }[\mathrm{m}]\end{array}$ & Shoreline development Catchment [ha] & $\begin{array}{c}\text { Catchment/lake area } \\
\text { ratio }\end{array}$ & $\begin{array}{c}\text { Catchment } \\
\text { character }\end{array}$ \\
\hline $54^{\circ} 01^{\prime} 41^{\prime \prime} \mathrm{N}$ & $23^{\circ} 03^{\prime} 21^{\prime \prime} \mathrm{E}$ & 8.9 & 9.6 & 1.78 & 107.1 & 12.03 & forested \\
\hline
\end{tabular}


period), beside remains of Sphagnum magellanicum (max. 60\%), leaves and branches of Sphagnum fallax (max. 20\%) are recognised. Periderm of Pinus sylvestris achieves $10 \%$, and remains of Eriophorum vaginatum, Ericaceae and brown mosses - max. 5\%. The last zone (SW-5; the Subatlantic period) is characterised by dominance of Sphagnum fallax (max 75\%). Leaves and branches of Sphagnum magellanicum achieve max. $20 \%$ of the sample volume.

Phases of marginal zone development were as follows: brown moss communities of fen (SW-1 zone; Allerød) $\rightarrow$ peat moss-pine communities of bog (SW$2-S W-3$ zones; Subboreal period) $\rightarrow$ peat moss communities of bog (SW-4- SW-5 zones; Subatlantic period).

The highest content of organic carbon (TOC) was noted in Sphagnum peat, where it exceeded 55\%, while the lowest (approximately 16\%) was noted in the sedge-brown moss peat (Table 2). The TKN content ranged from $1.88 \%$ in Sphagnum peat with $\mathrm{Pi}$ nus to $0.31 \%$ in sedge-brown moss peat (Table 2). Atomic C:N ratio achieved 37.60 - in Sphagnum peat, 28.88 in Sphagnum peat with Pinus, and almost twice more than this latter value, in sedge-brown moss peat (53.02). Sedge-brown moss peat was characterised also by the highest ash content (approximately 72\%) and minimal amount of $\mathrm{CaCO}_{3}$ (Table 2).

\section{Discussion}

Lake Suchar Wielki is one of the lakes originated during the main period of lake formation in young glacial areas - the Allerød (Błaszkiewicz 2007). The primary time of dead-ice melting occurred in this interstadial, when most of the warming during the Late Glacial period took place. The bottom peat sample in the marginal zone of studied lake was clas- sified as sedge-brown moss peat (Fig. 2). This peat was formed by brown moss communities indicating a high groundwater level in that time (Kloss 2005).

Despite high water level in water body, its marginal zone was terrestrial in character, which is indicated by the very small amount of nitrogen in sediment, atomic C:N value exceeding 20, and high content of mineral substances (Table 2). At the same time the C:N ratio indicates that the impact of terrestrial environment changed over time: the atomic $\mathrm{C}: \mathrm{N}$ ratio of sediment formed during the Late Glacial phase was almost twice higher than the one connected with the Subboreal period. Moreover the Late Glacial sediment is characterised by small amount of $\mathrm{CaCO}_{3}$ (Table 2). In this case the presence of carbonates is not directly connected with lake history (no charophyte remains in sediment), but should rather be considered as a result of calcium transport by free ground water circulation, which leached glacial deposits after slowly disappearing permafrost. The $d y$-type sediment was not recognised in the marginal zone of Lake Suchar Wielki, in contrast to lakesides of other humic lakes located in the territory of Wigry National Park, like Lake Suchar IV (Drzymulska and Zieliński 2013), Lake Suchar III, and Lake Suchar VI (Drzymulska et al. 2013).

During the development of Lake Suchar Wielki marginal zone, accumulation of biogenic sediments was interrupted for a long time. According to palynological data such interruption could cover the Younger Dryas, Preboreal, Boreal, and Atlantic periods (more than 7000 years). These strong perturbations, which are present in many of the profiles, are known as hiatuses (Digerfeldt et al. 2007). Certainly the interruption must be caused by local factors, because neither in Lake Wigry profiles (Kupryjanowicz 2007), nor in other humic lakes of this territory (Drzymulska et al. 2014) such hiatuses were observed.

Table 2. Typology and chemical parameters of sediments from the SW profile ( \pm standard deviation in brackets)

\begin{tabular}{|c|c|c|c|c|c|c|c|}
\hline $\begin{array}{l}\text { Depth } \\
{[\mathrm{cm}]}\end{array}$ & Sediment & $\begin{array}{c}\text { Mean TOC } \\
{[\%]}\end{array}$ & $\begin{array}{c}\text { Mean TKN } \\
{[\%]}\end{array}$ & $\begin{array}{c}\text { Ash content } \\
{[\%]}\end{array}$ & $\begin{array}{c}\mathrm{CaCO}_{3} \\
{[\%]}\end{array}$ & $\begin{array}{c}\text { Mean atomic } \\
\text { C:N }\end{array}$ & $\begin{array}{c}\text { Number } \\
\text { of samples }\end{array}$ \\
\hline $0-200$ & Sphagnum peat & $\begin{array}{c}55.65 \\
( \pm 0.23)\end{array}$ & $\begin{array}{c}1.48 \\
( \pm 0.33)\end{array}$ & $\begin{array}{c}4.03 \\
( \pm 0.41)\end{array}$ & - & $\begin{array}{c}32.23 \\
( \pm 7.36)\end{array}$ & 8 \\
\hline $200-270$ & Sphagnum peat with Pinus & $\begin{array}{c}54.31 \\
( \pm 1.77) \\
\end{array}$ & $\begin{array}{c}1.88 \\
( \pm 0.52)\end{array}$ & $\begin{array}{c}6.35 \\
( \pm 3.06) \\
\end{array}$ & - & $\begin{array}{c}24.76 \\
( \pm 10.11)\end{array}$ & 7 \\
\hline $270-300$ & sedge-brown moss peat & $\begin{array}{c}16.17 \\
( \pm 5.99)\end{array}$ & $\begin{array}{c}0.31 \\
( \pm 0.15)\end{array}$ & $\begin{array}{c}72.10 \\
( \pm 10.34)\end{array}$ & $\begin{array}{c}0.16 \\
( \pm 0.21)\end{array}$ & $\begin{array}{c}44.71 \\
( \pm 7.83)\end{array}$ & 3 \\
\hline $0-300$ & & $\begin{array}{c}42.04 \\
( \pm 17.31)\end{array}$ & $\begin{array}{c}1.25 \\
( \pm 0.41)\end{array}$ & $\begin{array}{c}27.49 \\
( \pm 26.86)\end{array}$ & $\begin{array}{c}0.16 \\
( \pm 0.21)\end{array}$ & $\begin{array}{c}28.83 \\
( \pm 8.39)\end{array}$ & 18 \\
\hline
\end{tabular}


On the other hand, we could suppose that accumulation was not interrupted totally, as confirmed by radiocarbon dating 7268-7116 cal. BP (Poz-38254) determined for the lowest sample from the SW-2 zone (Fig. 2). This dating indicates that accumulation took place in the Atlantic period, which is in opposition to palynological data. Probably younger and older sediments may be mixed and inverted in this layer, so the bottom sample of the SW-2 zone, which lay directly over the Allerød sediments, was older than anticipated basing on the pollen record. This mixing might be induced by intensive precipitation noted in NE Poland territory from the half of the Boreal period to the half of the Subboreal (Ralska-Jasiewiczowa and Starkel 1988). Such high precipitation could also induce sliding and slumping processes (Dearing 1997), what could result in mixing of sediments in the littoral zone. Such possibility was quite high because of steep southern slopes of Lake Suchar Wielki.

The cessation of these processes took place in the Subboreal period. During this phase floating mat was formed on the lakeside, and Sphagnum peat started to accumulate, initially strongly decomposed with abundant amount of pine remains, later - with only minimal amount of pine periderm, and slightly decomposed (Fig. 2). Water gaps (Fig. 2) probably occurred as the result of later water level increases, because they are not a consistent part of the mire. They were squeezed into the deposits from the marginal site towards the lake centre (Kowalewski and Barabach 2010). Low content of TKN and high atomic C:N ratio (Table 2) exhibit values typical of raised bog peat (Damman 1988; Kloss 2007). In the case of aquatic environment impact, evidenced by the presence of algae, phytoplankton, and zooplankton remains, we would expect large amounts of protein, hence the atomic C:N ratio would be lower (Krishnamurthy et al. 1986).

Occurrence of floating mat in the youngest phase of humic lake development was also noted in Lake Suchar Dębowskich (Żurek et al. 2009), Lake Suchar IV, Lake Wądołek (Drzymulska and Zieliński 2013), and Lake Suchar III (Drzymulska et al. 2013). In every case humus flowing into lakes from catchment basins (De Haan 1992; Hessen 1992) was sufficiently abundant to acidify water and to induce development of floating mat (Kullberg et al. 1993). However, in contrast to the other humic lakes, Lake Suchar Wielki is characterised by low value of catchment/lake area ratio. This parameter is as low as 12.03 (Table 2), while for Lake Suchar IV and Lake Suchar III it exceeds 72 (Drzymulska and Zieliński 2013; Drzymulska et al. 2013). Therefore, probably the most important factor impacting the marginal zone of the studied lake is the character of catchment, which is forested (Górniak and Zieliński 2000). The additional parameter promoting humus flow from catchment to the lake is high shoreline development index (1.78) (Górniak and Krzysztofiak 2006).

For a period of about 13000 years of history (from the Allerød to nowadays), despite the recognition of several phases of development, the studied lake indicates terrestrial character of marginal zone. Probably, the water body did not change distinctly in the past and possible environmental changes in its vicinity have no reflection in the sediment archive.

\section{Conclusion}

Lake Suchar Wielki is one of numerous lakes originated in the Allerød - the main period of lake formation in young glacial areas. Accumulation of sediments in the lake's marginal zone was interrupted because of slope processes stimulated by high precipitation. Hiatus could even include seven thousand years, as suggested by the results of pollen analysis. It is in contrast to radiocarbon dating determined for the oldest sediments of the SW-2 zone (Fig. 2). According to ${ }^{14} \mathrm{C}$ data the peat of this sample was formed in the Atlantic period, so not in the Subboreal, as we could suppose. Therefore accumulation could take place between the Allerød and the Subboreal time but certainly the process was not continuous. All interruptions in the region of Lake Suchar Wielki were stopped just in the Subboreal period and environmental conditions became stable. The lake started to function as a water body with spreading floating mat on water surface.

\section{Acknowledgements}

This work was supported by the Ministry of Science and Higher Education of Poland under project nr NN305085135 "History of dystrophic lakes of the Wigry National Park in the light of the Holocene succession of their vegetation". 


\section{References}

Bloesch J., 2004, Sedimentation and lake sediment formation, [in:] O'Sullivan P.E., Reynolds C.S. (eds), The Lakes Handbook. Limnology and limnetic ecology, Blackwell Publishing, Oxford: 197-229.

Błaszkiewicz M., 2007, Geneza i ewolucja mis jeziornych na mlodoglacjalnym obszarze Polski - wybrane problemy (Genesis and evolution of lake basins in the young-glacial territory of Poland - selected aspects), Stud. Lim. Tel. 1: 5-16 (in Polish).

Bremner J.M., Mulvaney C.S., 1982, Nitrogen-total, [in:] Page A.L. (ed), Agronomy No. 9, Methods of Soil Analysis, American Society of Agronomy, Madison: 595-624.

Bronk Ramsey C., 2013, OxCal. Version 4.2.3, Oxford Radiocarbon Accelerator Unit Research Laboratory for Archaeology, Oxford. Retrived from: http://c14.arch.ox.ac. $\underline{\mathrm{uk}}$

Charman D.J., 2002, Peatland and environmental change, Wiley, Chichester, p. 301.

Damman A.W.H., 1988, Regulation of nitrogen removal and retention in Sphagnum bogs and other peatlands, Oikos 4: 291-305.

De Haan H., 1992, Impacts of environmental changes on the biogeochemistry of aquatic humic substances, Hydrobiologia 229: 59-71.

Dearing J.A., 1997, Sedimentary indicators of lake-level changes in the humid temperate zone: a critical review, J. Paleolimnol. 18: 1-14.

Digerfeldt G., Sandgren P., Olsson S., 2007, Reconstruction of Holocene lake-level changes in Lake Xinias, central Greece, Holocene 17: 361-367.

Drzymulska D., Zieliński P., 2013, Developmental changes in the historical and present-day trophic status of brown water lakes. Are humic water bodies a uniform aquatic ecosystem?, Wetlands 33: 909-919.

Drzymulska D., Kłosowski S., Pawlikowski P., Zieliński P., Jabłońska E., 2013, The historical development of vegetation of foreshore mires beside humic lakes; different successional pathways under various environmental conditions, Hydrobiologia 703: 15-31.

Drzymulska D., Fiłoc M., Kupryjanowicz M., 2014, Reconstruction of landscape paleohydrology using the sediment archives of three dystrophic lakes in northeastern Poland, J. Paleolimnol. 51: 45-62.

Górniak A., Krzysztofiak L., 2006, Charakterystyka limnologiczna parku (Limnological charcateristic of the park), [in:] Górniak A. (ed), Jeziora Wigierskiego Parku Narodowego (Lakes of the Wigry National Park), Wyd. Uniwersytetu w Białymstoku, Białystok: 25-34 (in Polish).

Górniak A., Zieliński P., 2000, Influence of catchment characteristics and hydrology on dissolved organic carbon in rivers in north-eastern Poland, Verh. Internat. Verein Limnol. 27: 1142-1145.
Hessen D.O., 1992, Dissolved organic carbon in a humic lake: Effects on bacterial production and respiration, Hydrobiologia 229: 115-123.

Howard P.J.A., Howard D.M., 1990, Use of organic carbon and loss-on-ignition to estimate soil organic matter in different soil types and horizons, Biol. Fertil. Soils 9: 306-310.

Ji S., Xingqi L., Sumin W., 2005, Matsumoto R. Palaeoclimatic changes in the Qinghai Lake area during the last 18,000 years, Quat. Int. 136: 131-140.

Kloss M., 2005, Identification of subfossil plant communities and palaeohydrological changes in raised mire development, Monogr. Bot. 94: 81-116.

Kloss M., 2007, Roślinność subfosylna na tle historii wysokich torfowisk mszarnych w północno-wschodniej i środkowej Polsce oraz w Sudetach (Subfossil vegetation in the light of history of sphagnum raised mires in the north-eastern and central Poland as well as in the Sudety Mountains), Instytut Badawczy Leśnictwa, Sękocin Stary, p. 141 (in Polish, English summary).

Kondracki J., 1994, Geografia Polski. Mezoregiony fizycznogeograficzne, PWN, Warszawa, p. 340 (in Polish).

Kowalewski G., Barabach J., 2010, Struktura osadów zbiornika jeziorno-torfowiskowego Dury V (Bory Tucholskie) (Sedimentary record in lake-mire basin Dury V (Tuchola Pinewood Forest)), Stud. Lim. Tel. 4: 65-74 (in Polish).

Krishnamurthy R.V., Bhattacharya S.K., Kusumgar S., 1986, Palaeoclimatic changes deduced from $13 \mathrm{C} / 12 \mathrm{C}$ and $\mathrm{C} / \mathrm{N}$ ratios of Karewa lake sediments, India, Nature 323: 150-152.

Kullberg A., Bishop K.H., Hargeby A., Jonson M., Petersen R.C., 1993, The ecological significance at dissolved organic carbon in acidified water, Ambio 22: 331-337.

Kupryjanowicz M., 2007, Postglacial development of vegetation in the vicinity of the Wigry Lake, Geochronometria 27: 53-66.

Marks L., 2002, Last Glaciation maximum in Poland, Quat. Sci. Rev. 21:103-110.

Meyers P.A., 1994, Preservation of elemental and isotopic source identification of sedimentary organic matter, Chem. Geol. 114: 289-302.

Obidowicz A., 1990, Eine Pollenanalytische und Moorkundliche Studie zur Vegetationsgeschichte des Podhale-Gebietes (West-Karpaten) (Palinological and peat-science research of vegetation history of the Podhale region (Western Carpathians)), Acta Palaeobot. 1(2): 147-219 (in German).

Pawlikowski P., Rutkowska E., Kłosowski S., Jabłońska E., Drzymulska D., 2013, Development of bog-like vegetation during terrestrialization of polyhumic lakes in north-eastern Poland is not accompanied by ecosystem ombrotrophication, Hydrobiologia DOI: 10.1007/ s10750-013-1783-3. 
Ralska-Jasiewiczowa M., Starkel L., 1988, Record of the hydrological changes during the Holocene in the lake, mire and fluvial deposits of Poland, Folia Quat. 57: 91-126.

Ralska-Jasiewiczowa M., Latałowa M., Wasylikowa K., Tobolski K., Madeyska E., Wright Jr H.E., Turner C.H., 2004, Late Glacial and Holocene history of vegetation in Poland based on isopollen maps, W. Szafer Institute of Botany, Polish Academy of Sciences, Kraków, p. 395.

Rydin H., Jeglum J., 2008, The biology of peatlands, Oxford University Press, Oxford, p. 343.
Tołpa S., Jasnowski M., Pałczyński A., 1967, System der genetischen Klassifizierung der Torfe Mitteleuropas (System of genetic classification of peats from Middle Europe), Zesz. Probl. Post. Nauk Rol. 79: 9-99 (in German).

Walanus A., Nalepka D., 1999, Polpal Program for counting pollen grains, diagrams plotting and numerical analysis, Acta Palaeobot. 2: 659-661.

Żurek S., Bińka K., Drzymulska D., 2009, Torfowisko Sucharu Dembowskich (Suchar Dembowskich mire), Pr. Kom. Paleogeogr. Czwartorzędu PAU 7: 99-106 (in Polish). 